\title{
Virologic failure in HIV-positive adolescents with perfect adherence in Uganda: a cross- sectional study
}

\author{
Julian Natukunda ${ }^{1,2^{*}}$, Peter Kirabira', Ken Ing Cherng Ong ${ }^{2}$, Akira Shibanuma ${ }^{2}$ and Masamine Jimba ${ }^{2}$
}

\begin{abstract}
Background: Adolescents living with human immunodeficiency virus (HIV) die owing to acquired immune deficiency syndrome (AIDS)-related causes more than adults. Although viral suppression protects people living with HIV from AIDS-related illnesses, little is known about viral outcomes of adolescents in sub-Saharan Africa where the biggest burden of deaths is experienced. This study aimed to identify the factors associated with viral load suppression among HIV-positive adolescents (10-19 years) receiving antiretroviral therapy (ART) in Uganda.

Methods: We conducted a cross-sectional study among school-going, HIV-positive adolescents on ART from August to September 2016. We recruited 238 adolescents who underwent ART at a public health facility and had at least one viral load result recorded in their medical records since 2015. We collected the data of patients' demographics and treatment- and clinic-related factors using existing medical records and questionnaire-guided face-to-face interviews. For outcome variables, we defined viral suppression as $<1000$ copies $/ \mathrm{mL}$. We used multivariate logistic regression to determine factors associated with viral suppression.
\end{abstract}

Results: We analyzed the data of 200 adolescents meeting the inclusion criteria. Viral suppression was high among adolescents with good adherence $>95 \%$ (adjusted odds ratio [AOR] 2.73, 95\% confidence interval [95\% Cl, 1.09 to 6.82). However, $71 \%$ of all adolescents who did not achieve viral suppression were also sufficiently adherent (adherence $>95 \%$ ). Regardless of adherence status, other risk factors for viral suppression at the multivariate level included having a history of treatment failure (AOR 0.26, 95\% Cl, 0.09 to 0.77), religion (being Anglican [AOR 0.19, $95 \% \mathrm{Cl}, 0.06$ to 0.62 ] or Muslim [AOR $0.17,95 \% \mathrm{Cl}, 0.05$ to 0.55$]$ ), and having been prayed for (AOR $0.38,95 \% \mathrm{Cl}$, 0.15 to 0.96$)$.

Conclusion: More than $70 \%$ of adolescents who experienced virologic failure were sufficiently adherent (adherence > 95). Adolescents who had unsuppressed viral loads in their initial viral load were more likely to experience virologic failure upon a repeat viral load regardless of their adherence level or change of regimen. The study also shows that strong religious beliefs exist among adolescents. Healthcare provider training in psychological counseling, regular and strict monitoring of adolescent outcomes should be prioritized to facilitate early identification and management of drug resistance through timely switching of treatment regimens to more robust combinations.

Keywords: Human immunodeficiency virus (HIV), Adherence, Adolescents, Viral suppression, Virologic failure, Antiretroviral therapy

\footnotetext{
* Correspondence: jknatukunda@gmail.com

${ }^{1}$ Public Health and Management, Institute of Health, International Health Sciences University, Kampala, Uganda

${ }^{2}$ Department of Community and Global Health, Graduate School of

Medicine, The University of Tokyo, Tokyo, Japan
}

(c) The Author(s). 2019 Open Access This article is distributed under the terms of the Creative Commons Attribution 4.0 International License (http://creativecommons.org/licenses/by/4.0/), which permits unrestricted use, distribution, and reproduction in any medium, provided you give appropriate credit to the original author(s) and the source, provide a link to the Creative Commons license, and indicate if changes were made. The Creative Commons Public Domain Dedication waiver (http://creativecommons.org/publicdomain/zero/1.0/) applies to the data made available in this article, unless otherwise stated. 


\section{Introduction}

In many countries, the "treat all" approach is implemented to identify HIV-positive people earlier and get them on treatment. Its goal is to suppress viral replication by maintaining high levels of adherence to antiretroviral therapy (ART). These efforts are part of the global response toward achieving "the third 90" in the 90-90-90 targets, an initiative to end the AIDS epidemic as a public health threat by 2030 .

Briefly, the Joint United Nations Program on HIV and AIDS' $90-90-90$ campaign aims to have $90 \%$ of people living with HIV to know their status, have $90 \%$ of people living with HIV who know their status start or maintain their treatment, and have $90 \%$ of people on treatment to be virally suppressed by 2020 . Achieving viral suppression protects people living with HIV from acquired immune deficiency syndrome (AIDS)-related illnesses and lowers the risk of transmission to others. In 2016, however, only $44 \%$ of the people living with HIV who were on treatment had viral suppression globally [1].

To improve viral suppression, adolescents should be more cared for. This is because, globally, up to 150 adolescents die every day due to AIDS-related illnesses. In 2016, 91\% of adolescent deaths worldwide were reported in sub-Saharan Africa, and the rate of AIDS-related deaths among this age group have not reduced [2, 3]. In addition, children and adolescents from different parts of the world had worse viral suppression outcomes than adults [4-6].

So far, barriers to and factors that promote viral suppression have been identified. Commonly cited barriers among adolescents include pill burden, medication taste, secrecy/stigma, drug toxicity and resistance, clinic-related factors, being sick, missed appointments, loss of a mother, strong religious beliefs, and poor knowledge about HIV, among others [7-11]. On the contrary, promoting factors have also been identified: use of community interventions [12], setting up adolescent-specific care spaces [13], and maintaining adherence > 95\% [4]. However, most of the recommendations from these studies require financial support, which is scarcely available in low-income countries, and interventions may collapse once support is withdrawn. Therefore, more cost-effective interventions are needed.

Uganda ranked among the top 20 high burden countries contributing $5 \%$ of AIDS-related deaths among adolescents in 2014 [14]. The deaths are attributed to the late diagnosis and poor access to treatment with most perinatally infected children starting treatment later in life. Like other countries, Uganda committed to achieve the $90-90-90$ targets by 2020; however, the country is still short on achieving the ambitious target with the third 90 scoring lowest along the cascade. In 2017, about $73 \%$ of the people living with HIV knew their HIV status; $67 \%$ were enrolled on ART; while almost $60 \%$ had achieved viral suppression [15]. To identify people living with HIV who are likely to fail on treatment (including adolescents) and monitor their quality of life, the Uganda Ministry of Health recommended viral load testing for all people who are receiving ART for at least 6 months or more. Children under 15 years continued to have much lower rates of viral suppression compared to adults $[4,15,16]$.

Although adherence to ART is important for viral suppression, some children and adolescents are sufficiently adherent but their viral loads remain high, while others have suppressed viral loads despite poor adherence [17-19]. In Uganda, information on viral suppression among adolescents aged 10-19 years is limited. This is because the age disaggregation groups adolescents $10-15$ years with children aged $0-14$ years while those 16-19 years are considered among adults. It is therefore difficult to ascertain outcomes of adolescents on ART with the current data [15]. This study aimed to identify the factors associated with viral suppression among adolescents aged 10-19 years and characteristics of sufficiently adherent adolescents who fail to achieve viral suppression.

\section{Materials and methods Study design}

We conducted a cross-sectional study of HIV-positive adolescents receiving ART at Jinja Regional Referral Hospital (RRH), Uganda, from August to September 2016. To assess the individual and socio-demographic factors associated with viral suppression, we conducted face-to-face interviews using semi-structured questionnaires. Additionally, using a data extraction tool developed in Excel, we collected secondary (retrospective) data on ART-related factors such as duration of ART, CD4 count at initiation, adherence status (past 12 months), treatment failure, World Health Organization clinical staging, and nutritional status. We developed the data extraction tool based on screening key indicators monitored nationally using the individual medical card, viral load register, and electronic database.

\section{Study area}

We conducted this study at Jinja Regional Referral Hospital-a public referral center for complicated cases and specialized laboratory tests in the East Central region, Uganda. The hospital runs a separate wing for children, pediatrics, and adolescents. Adolescents living with HIV aged 18 years are transferred to the adult HIV clinic located $3 \mathrm{~m}$ away from the main hospital. Health workers regularly offer pre-regimen and adherence counseling, discuss appointment schedules, probe for other illnesses, and explain viral load outcomes to 
adolescents and caretakers at every clinical review appointment.

In June 2016, over 600 adolescents at Jinja RRH were given ART. Of them, 397 adolescents were actively attending their scheduled clinical review appointments; only 238 adolescents had access to a viral load test. Mass viral load monitoring using viral load testing begun in 2015 at this hospital. Using the viral load national testing algorithm, children and adolescents below 20 years are required to have a viral load done every 6 months [20]. The study period coincided with school holidays where adolescents could be easily seen, and appointments had been scheduled to coincide with the adolescent clinic day.

\section{Study participants}

HIV-positive adolescents (10-19 years) who received ART for at least 6 or more months at Jinja RRH and had viral load results in their medical records were included in this study. The viral load results considered in this study were those documented between 1 January 2015 to 31 July 2016. We obtained assent from the caretakers of adolescents aged 10-14 years and consent from adolescents aged 15-19 years. We selected 238 adolescents to participate in the study from the total eligible adolescents enrolled on ART using Open Medical Records System (OpenMRS), an electronic database.

\section{Sample size calculation}

Given the total population of 600 HIV-positive adolescents, 397 adolescents (10-19 years) were receiving ART at Jinja RRH's Nalufenya children's and adult HIV clinic. Of the 397 adolescents, 238 had accessed a viral load test in the past 2 years.

Using Sloven's formula

$$
n=\frac{N}{\left(1+\mathrm{Ne}^{2}\right)}
$$

The total number of adolescents required for our study was approximately 209 . We therefore decided to study all the adolescents, whose files contained viral load results, representing $60 \%$ of the study target population.

\section{Data collection}

The primary outcome was viral suppression defined as viral load < 1000 copies/mL [21]. We collected individual viral load results and suppression status from the viral load result forms kept in the medical files. We used the most recent viral load results for adolescents (results documented between January 2015 and July 2016). For other treatment-related factors, we used data from individual ART cards and electronic medical records
(OpenMRS) software. For example, we extracted data on adherence status from the ART cards, which tracked the adherence of each adolescent for the past 12 months before their latest viral load test. For adolescents who were on ART for less than 12 months, we calculated the adherence rate based on the total number of months spent on treatment (at least 6 months). Medication adherence in this study was referred to as the degree to which adolescents took their prescribed medicines (includes dosage, time of the day) using pill counts as a primary measure. Adolescents' adherence was described as good, fair, or poor based on the following; G (good) $>95 \%$, F (fair) if between $85 \%$ and $94 \%$, and P (poor) < $85 \%$ [20]. According to the ART card summary guide (at the bottom of the generic ART card), the level of adherence was estimated using the number of missed doses per month based on a twice daily regimen. For example, if an adolescent missed 3 or less doses in a month, adherence was documented as good; if 4-8 doses were missed, it would be recorded as fair adherence, and 9 or more missed doses implied poor adherence. Other variables from ART cards included age, sex, regimen type [20], CD4 count, appointment keeping, history of treatment failure, nutritional status, clinical stage, opportunistic infection, treatment start date, and counseling after treatment $[4,20]$.

\section{Sociodemographic variables}

We collected information about age and sex using face-to-face questionnaires to cross examine information collected from the medical cards. In addition, we asked questions about level of education, religion, being prayed for, believing in God or Allah healing their illness, having both parents alive, perceived family support [9, 22], level of satisfaction of health services offered, convenience of scheduled appointments, and staying with a family member who is HIV positive [23, 24].

We recruited eight field assistants (particularly those working within the HIV clinic) to collect data and trained them on how to fill the data tools, resolve issues related to obtaining consent, and perform procedures according to ethical standards. The data assistants collected information from the patient cards into a data extraction tool. They then conducted face-to-face interviews and filled out questionnaires as they interacted with adolescents and their care givers during scheduled clinical review appointments. Whereas the field assistants were conversant with the local dialect, they had no formal connections with the respective adolescents, which minimized any bias in responses to the subjects. In addition, while extensive training was offered to the field assistants to fully acquaint them with the data collection procedures, they were ignorant about the study outcome. The counselors further contacted caregivers of 
adolescents whose appointments had passed or were scheduled on a future date to come with their children to the clinic using phone calls. We validated the data abstraction tool and pretested semi-structured questionnaires before the study.

\section{Data analysis}

We coded and entered quantitative data from study tools into a predesigned Excel spreadsheet and performed statistical analyses using STATA version 13.1 (College Station, TX, USA). We also performed descriptive analyses and summarized data on continuous variables such as age, viral load, and mean and their corresponding standard deviations. Then, we summarized the categorical variables including sex, viral suppression, and religion, among others, as proportions. For binary outcomes, we obtained odds ratio for each independent variable, adjusting for suppression. We performed multiple logistic regression analyses and chi-square tests to determine any possible association at $95 \%$ confidence level. Since CD4 count at initiation had missing baseline values, we performed multiple imputations (10 imputations) using variables associated with the outcome variable. While we did not have a command for variance inflation factor in stata in the case of multiple imputation, we checked variance inflation factor without multiple imputation and did not find multicollinearity. We included significant $(P \leq 0.05)$ variables and other variables that were not considered significant but were reported to influence viral outcomes in the final model $[4,9,13]$. Finally, we included all variables with $P$ value $<0.05$ from our multivariable analysis as independent predictors of viral suppression in this population.

\section{Ethical considerations}

We obtained a waiver from the International Health Sciences University's Degree Research and Ethics Committee. The reason for the waiver was that the study had no potential to cause harm whether physical or psychological to the participants. The decision was based on the National Guidelines for Research involving humans as research participants developed by the Uganda National Council for Science and Technology. We also obtained permission from the hospital administration to conduct the study. We sought an informed consent for adolescents aged 15 years and above, or informed assent from parents/ caretakers of adolescents aged below 15 years. To ensure confidentiality, we assigned study participants with unique identifiers.

\section{Results}

General characteristics

Table 1 shows the basic characteristics of adolescents. Overall, 200 adolescents participated in the study. The
Table 1 Socio-demographic and client-related characteristics of adolescents $(n=200)$

\begin{tabular}{|c|c|c|c|}
\hline \multirow{2}{*}{\multicolumn{2}{|c|}{$\begin{array}{l}\text { Characteristics } \\
\text { Age mean (standard deviation, SD) }\end{array}$}} & \multirow{2}{*}{\multicolumn{2}{|c|}{$\frac{n}{13.2(2.4)}$}} \\
\hline & & & \\
\hline \multirow[t]{2}{*}{ Viral suppression } & Yes & 131 & 65.5 \\
\hline & No & 69 & 34.5 \\
\hline \multirow[t]{2}{*}{ Sex } & Male & 104 & 52.0 \\
\hline & Female & 96 & 48.0 \\
\hline \multirow[t]{5}{*}{ Education } & Primary & 151 & 75.5 \\
\hline & Ordinary & 39 & 19.5 \\
\hline & Advanced & 4 & 2.0 \\
\hline & Tertiary & 3 & 1.5 \\
\hline & No education & 3 & 1.5 \\
\hline \multirow[t]{2}{*}{ Perceived family support } & Yes & 162 & 81.0 \\
\hline & No & 38 & 19.0 \\
\hline \multirow[t]{2}{*}{ Other family member with HIV } & Yes & 133 & 66.5 \\
\hline & No & 67 & 33.5 \\
\hline \multirow{2}{*}{$\begin{array}{l}\text { Adolescent attending clinic in } \\
\text { the same space as adults }\end{array}$} & Yes & 148 & 74.0 \\
\hline & No & 52 & 26.0 \\
\hline \multirow[t]{4}{*}{ Religion } & Catholic & 47 & 23.5 \\
\hline & Anglican & 64 & 32.0 \\
\hline & Muslim & 59 & 29.5 \\
\hline & Other & 30 & 15.0 \\
\hline \multirow[t]{2}{*}{ Ever been prayed for } & Yes & 95 & 47.5 \\
\hline & No & 105 & 52.5 \\
\hline \multirow[t]{2}{*}{ Believe in God healing their illness } & Yes & 149 & 74.5 \\
\hline & No & 51 & 25.5 \\
\hline Both parents alive & Yes & 83 & 41.0 \\
\hline \multirow[t]{3}{*}{ Disclosure among family members } & No & 117 & 59.0 \\
\hline & Yes & 158 & 79.0 \\
\hline & No & 42 & 21.0 \\
\hline
\end{tabular}

mean age was 13.2 (standard deviation: 2.4) years, and $52 \%$ of them were male adolescents. Of the 200 adolescents, 131 (65.5\%) achieved viral suppression. Over 75\% of adolescents attended primary level education and received support from their family members such as accommodation, feeding, and education. The HIV status of nearly $80 \%$ of the adolescents was known among family members. About $65 \%$ of adolescents lived with at least one family member of the same HIV status in one household. Adolescents belonged to either one of the following religious denominations: Catholic, Anglican, Muslim, and others. In addition, $75 \%$ of the adolescents attended clinic services in the same space as adults and believed in God healing their illness.

Table 2 presents the univariate (regimen-and treatment-related) characteristics of adolescents. Over $50 \%$ had been on treatment for 5 or more years while 
Table 2 Univariate treatment characteristics of adolescents

\begin{tabular}{|c|c|c|c|}
\hline Characteristics & & $n$ & $\%$ \\
\hline \multirow[t]{3}{*}{ Years on ART (years) } & $0-2$ & 35 & 17.5 \\
\hline & $3-5$ & 59 & 29.5 \\
\hline & More than 5 & 106 & 53.0 \\
\hline \multirow[t]{4}{*}{ CD4 count at initiation (cells/mL) } & More than 500 & 54 & 27.0 \\
\hline & $200-499$ & 45 & 22.5 \\
\hline & Less than 200 & 43 & 21.5 \\
\hline & Missing & 58 & 29.0 \\
\hline \multirow[t]{2}{*}{ Adherence status } & Good $>95 \%$ & 160 & 80.0 \\
\hline & Fair/poor <95\% & 40 & 20.0 \\
\hline \multirow[t]{2}{*}{ History of treatment failure } & Yes & 29 & 14.5 \\
\hline & No & 171 & 85.5 \\
\hline \multirow[t]{4}{*}{ WHO clinical stage } & 1 & 143 & 86.1 \\
\hline & $\|$ & 6 & 3.6 \\
\hline & III & 15 & 9.1 \\
\hline & IV & 2 & 1.2 \\
\hline \multirow[t]{3}{*}{ Nutritional status } & Normal & 150 & 89.8 \\
\hline & MAM & 13 & 7.8 \\
\hline & SAM & 4 & 2.4 \\
\hline \multirow[t]{3}{*}{ Regimen } & $\mathrm{AZT}+3 \mathrm{TC}+\mathrm{EFV}$ & 76 & 38.0 \\
\hline & $A Z T+3 T C+N V P$ & 116 & 58.0 \\
\hline & $\mathrm{ABC}+3 \mathrm{TC}+\mathrm{EFV}$ & 8 & 4.0 \\
\hline
\end{tabular}

over $80 \%$ had good adherence above 95\%, had never experienced treatment failure and belonged to clinical stage 1 . Overall, about $90 \%$ adolescents had a normal nutritional status.

Table 3 shows the regimen and health-related characteristics of 200 adolescents with or without viral suppression. Both in the suppression and non-suppression groups, more than $50 \%$ of adolescents spent at least 5 or more years on ART and were started on the same regimen $(\mathrm{AZT}+3 \mathrm{TC}+\mathrm{NVP})$. Over $70 \%$ of adolescents had good adherence (>95\%) and no history of treatment failure. About $85 \%$ of adolescents had WHO clinical stage I, while more than $90 \%$ had normal nutritional status. However, CD4 counts of the adolescents at the start of ART varied largely between the two groups. For the suppression group, the proportion of adolescents who achieved viral suppression increased with increasing CD4 counts at ART initiation $[16 \%$ (CD $4<200$ cells), 23\% (CD4 200-499 cells), and 34\% (CD4 > 500 cells], while more adolescents in the non-suppression group tended to have lower CD4 counts at ART initiation [30\% (CD4 $<200$ cells), 22 (CD4; 200-499 cells), and 15\% (CD4 $>500$ cells)].

Table 4 shows the factors associated with viral suppression among adolescents when all variables were regressed. At multivariate level, an adherence rate of $>95 \%$ (AOR 2.73, 95\% CI 1.09 to 6.82) was associated with viral suppression. Adolescents were less likely to achieve viral suppression if they belonged to the following categories: those who had a history of treatment failure (AOR 0.26, 95\% CI 0.09 to 0.77 ) and had normal nutritional status (AOR 0.11, 95\% CI 0.02 to 0.67). In addition, being Anglican (AOR 0.19, 95\% CI 0.06 to 0.62) or Muslim (AOR 0.17, 95\% CI 0.05 to 0.55 ) and having ever been prayed for $(\mathrm{AOR}=0.38, P<0.05)$ were risk factors of viral suppression.

Additional file 1: Table S1 shows detailed individual and treatment characteristics of 49 adolescents who were adherent (>95\%) but failed to achieve viral suppression. Of the 49 adolescents, 7 (14.3\%) had experienced treatment interruptions (missed medication) at least once in 12 months. The remaining 42 adolescents had medication adherence of $100 \%$ across all the 12 months. In this group, male adolescents (63\%) constituted the biggest percentage. Likewise, all the 4 (8\%) adolescents who were malnourished were men and belonged to clinical stage III. A total of 34 (69\%) adolescents had their CD4 counts at ART initiation documented; about 18 adolescents had CD $4<200$ cells $/ \mathrm{mL}$, 10 had 200-499 cells/mL, and only 6 had $>500$ cells/ $\mathrm{mL}$. About $75 \%$ of 49 adolescents had been on treatment for 5 or more years.

\section{Discussion}

Out of 200 adolescents, 69 (34.5\%) did not achieve viral suppression. Of $69,71 \%$ had a good adherence (above $95 \%)$. Altogether, adolescents in the study had a low viral suppression rate than recommended in the 90-90-90 targets despite having good adherence. It is possible that the number of HIV-positive people with good adherence who have poor viral outcomes is increasing, especially in developing countries where treatment options are not regularly updated. This is one of the few studies which reports sufficiently adherent adolescents with no history of treatment interruptions failing to achieve viral suppression. Some of the characteristics of these adolescents include being on a regimen containing nevirapine at initiation and having a history of treatment failure.

In this study, the viral failure rate among adolescents on ART was $34.5 \%$. This rate is higher than that reported for low- and middle-income countries (29\%), and in South Africa (19\%) [5, 10]. However, a study conducted in Zimbabwe and another recently concluded study in Uganda reported slightly higher rate of viral failure (43\%) among children and adolescents on ART $[25,26]$. The study results which show increasing rates of HIV drug resistance (HIVDR) are in line with recent findings by WHO showing an increase in levels of 
Table 3 Treatment- and health-related characteristics of adolescents and viral suppression

\begin{tabular}{|c|c|c|c|c|c|}
\hline \multirow[t]{2}{*}{ Characteristics } & & \multicolumn{2}{|c|}{ Achieved viral suppression $(n=131)$} & \multicolumn{2}{|c|}{ No viral suppression $(n=69)$} \\
\hline & & $n$ & $\%$ & $n$ & $\%$ \\
\hline \multirow[t]{2}{*}{ Viral suppression } & Men & 63 & 48.0 & 41 & 59.0 \\
\hline & Women & 68 & 52.0 & 28 & 41.0 \\
\hline \multirow[t]{3}{*}{ Years on ART (years) } & $0-2$ & 28 & 21.4 & 7 & 10.1 \\
\hline & $3-5$ & 36 & 27.5 & 23 & 33.3 \\
\hline & More than 5 & 67 & 51.1 & 39 & 56.5 \\
\hline \multirow[t]{4}{*}{ CD4 count at initiation (cells/mL) } & More than 500 & 44 & 33.6 & 10 & 14.5 \\
\hline & 200-499 & 30 & 22.9 & 15 & 21.7 \\
\hline & Less than 200 & 22 & 16.8 & 21 & 30.4 \\
\hline & Missing & 35 & 26.7 & 23 & 33.3 \\
\hline \multirow[t]{2}{*}{ Adherence status } & Good $>95 \%$ & 111 & 84.7 & 49 & 71.0 \\
\hline & Fair/poor $<95 \%$ & 20 & 15.3 & 20 & 29.0 \\
\hline \multirow[t]{2}{*}{ History of treatment failure } & Yes & 10 & 7.6 & 19 & 27.5 \\
\hline & No & 121 & 92.4 & 50 & 72.5 \\
\hline \multirow[t]{4}{*}{ WHO clinical stage } & । & 116 & 88.5 & 58 & 84.1 \\
\hline & $\|$ & 3 & 2.3 & 3 & 4.3 \\
\hline & III & 8 & 6.1 & 8 & 11.6 \\
\hline & IV & 4 & 3.1 & & \\
\hline \multirow[t]{3}{*}{ Nutritional status } & Normal & 118 & 90.0 & 65 & 94.2 \\
\hline & MAM & 9 & 6.9 & 4 & 5.8 \\
\hline & SAM & 4 & 3.1 & & \\
\hline \multirow[t]{3}{*}{ Regimen } & $A Z T+3 T C+E F V$ & 7 & 35.9 & 29 & 42.0 \\
\hline & $A Z T+3 T C+N V P$ & 77 & 58.8 & 39 & 56.5 \\
\hline & $A B C+3 T C+E F V$ & 7 & 5.3 & 1 & 1.5 \\
\hline
\end{tabular}

HIVDR even in the context of well-managed HIV treatment programs [27].

This study found that an adherence rate of $>95 \%$ was positively associated with viral suppression, and $65.5 \%$ of adolescents achieved viral suppression. However, even when adherence was more than $95 \%, 71 \%$ of 69 adolescents failed to achieve viral suppression. This failure might be explained as follows: first, from the Additional file 1: Table S1, regimen-specific differences were more pronounced in adolescent males, especially those enrolled on a treatment combination consisting of nevirapine (AZT + 3TC + NVP). From the Additional file 1: Table S1, 57\% of the adolescents who experienced virologic failure were on a nevirapine combination. However, apart from the skin rash, no specific adverse events were reported among adolescents on this regimen. Nevirapine use, in the past, was known to be associated with increased risk of ART failure [28, 29]. In sub-Saharan Africa, however, treatment combination options remain largely unchanged for HIV-positive people, and transition to more robust regimens is costly.
Second, the time spent on ART should be considered. Longer exposure to ART (5 years and above) was a common characteristic among adolescents who failed to achieve viral suppression. This finding is consistent with that reported in studies conducted in Northwest Ethiopia [30] and Swaziland [31]. Because long-term ART is common in perinatally infected children transitioning into young adults, viral failure may be explained by the possible accumulation of drug resistance mutations over time (adherence to a failing regimen).

Third, only $14.3 \%$ of the 49 adolescents with good adherence who failed to achieve viral suppression had experienced treatment interruptions at least once in 12 months. Missed antiretroviral doses or interruptions in therapy may result in HIV drug resistance hence virologic failure [32]. Some studies have reported low adherence for people with strong spiritual beliefs who tend to delay or miss medication during fasting, after being baptized with holy water [10], or after receiving healing prayers [11]. Although treatment interruptions were indicated by a "fair" or "poor" adherence status in the medical files, there was no specific explanation about 
Table 4 Factors associated with viral suppression among adolescents on ART

\begin{tabular}{|c|c|c|c|c|}
\hline \multirow[t]{2}{*}{ Variables } & & \multicolumn{3}{|c|}{ Adjusted model } \\
\hline & & $\mathrm{AOR}$ & $\mathrm{Cl}$ & $P$ value \\
\hline Age & & 1.01 & $0.82-1.23$ & 0.95 \\
\hline \multirow[t]{2}{*}{ Sex } & Male & 1.00 & & \\
\hline & Female & 1.49 & $0.72-3.08$ & 0.28 \\
\hline \multirow[t]{2}{*}{ Education level } & Primary & 1.00 & & \\
\hline & Ordinary, advanced, and tertiary & 0.65 & $0.24-1.81$ & 0.42 \\
\hline \multirow[t]{2}{*}{ Perceived family support } & No & 1.00 & & \\
\hline & Yes & 1.72 & $0.36-8.21$ & 0.49 \\
\hline \multirow[t]{2}{*}{ Disclosure among family members } & No & 1.00 & & \\
\hline & Yes & 1.53 & $0.38-6.12$ & 0.55 \\
\hline \multirow[t]{4}{*}{ Religion } & Catholic & 1.00 & & \\
\hline & Anglican & 0.19 & $0.06-0.62$ & 0.01 \\
\hline & Muslim & 0.17 & $0.05-0.55$ & 0.003 \\
\hline & Other & 0.42 & $0.12-1.49$ & 0.18 \\
\hline \multirow[t]{3}{*}{ Years on ART } & $0-2$ years & 1.00 & & \\
\hline & $3-5$ years & 0.61 & $0.16-2.42$ & 0.49 \\
\hline & More than 5 years & 0.74 & $0.19-2.81$ & 0.66 \\
\hline \multirow[t]{3}{*}{ CD4 count at initiation } & $>500$ cells $/ \mathrm{mL}$ & 1.00 & & \\
\hline & 200-499 cells/mL & 0.44 & $0.15-1.35$ & 0.15 \\
\hline & $<200$ cells $/ \mathrm{mL}$ & 0.27 & $0.07-1.02$ & 0.05 \\
\hline \multirow[t]{2}{*}{ Adherence status } & Poor/Fair & 1.00 & & \\
\hline & Good & 2.73 & $1.09-6.82$ & 0.03 \\
\hline \multirow[t]{2}{*}{ Treatment failure } & No & 1.00 & & \\
\hline & Yes & 0.26 & $0.09-0.77$ & 0.01 \\
\hline \multirow[t]{2}{*}{ WHO clinical stage } & Stages | and || & 1.00 & & \\
\hline & Stages III and IV & 0.65 & $0.17-2.45$ & 0.52 \\
\hline \multirow[t]{2}{*}{ Nutritional status } & Moderate/severely malnourished & 1.00 & & \\
\hline & Normal & 0.11 & $0.02-0.67$ & 0.02 \\
\hline \multirow[t]{3}{*}{ Regimen } & $\mathrm{AZT}+3 \mathrm{TC}+\mathrm{EFV}$ & 1.00 & & \\
\hline & $A Z T+3 T C+N V P$ & 1.36 & $0.56-3.27$ & 0.49 \\
\hline & $\mathrm{ABC}+3 \mathrm{TC}+\mathrm{EFV}$ & 3.22 & $0.28-44.06$ & 0.33 \\
\hline \multirow[t]{2}{*}{ Attending clinic in the same space with adults } & No & 1.00 & & \\
\hline & Yes & 0.54 & $0.22-1.35$ & 0.19 \\
\hline \multirow[t]{2}{*}{ Ever been prayed for } & No & 1.00 & & \\
\hline & Yes & 0.38 & $0.15-0.96$ & 0.04 \\
\hline \multirow[t]{2}{*}{ Believe in God healing their illness } & No & 1.00 & & \\
\hline & Yes & 2.61 & $0.87-7.81$ & 0.09 \\
\hline \multirow[t]{2}{*}{ Another member living with HIV in the same household } & No & 1.00 & & \\
\hline & Yes & 1.35 & $0.61-2.99$ & 0.46 \\
\hline
\end{tabular}

Notes: $n=200$

the nature of the interruptions and how long they lasted within the month. More so, information about interruptions was obtained via individual self-reports which are subject to bias. Future research should prioritize inventing a daily measure or tool for capturing treatment interruptions.

In this study, $15 \%$ of 131 HIV-positive adolescents with poor adherence $(<95 \%)$ achieved viral suppression. 
This finding is consistent with those reported in other studies [17-19]. The Uganda Ministry of Health Guidelines recommend intensive adherence counseling for 6 weeks for anyone with high viral loads (>1000 copies) and a repeat viral load test conducted after the third intensive adherence counseling session. In our study, 168 $(84 \%)$ adolescents had a repeat viral load result in their files overall. Of these, 61 (78\%) of the adolescents had unsuppressed viral load after a repeat viral load. In this case, intensive adherence counseling would not be a priority for such adolescents; instead, efforts should be focused on understanding facilitators of viral suppression among this group. Furthermore, many countries have a limited number of health workers trained in adolescent health services [33]. Training of all health workers in adolescent health service delivery may address existing challenges and provide better understanding of the promoting factors and barriers to suppression among this age group.

Adolescents were less likely to achieve viral suppression if they had previously failed on treatment [4], were Muslim or Anglican, and had ever been prayed for. Contrary to our expectations, WHO clinical stage, duration of treatment, CD4 count [31], family support, and sharing clinic space were not associated with viral suppression. These findings were also contrary to those of other studies conducted in Zimbabwe [13], Tanzania [22], and Ethiopia [28], which indicated that family support and establishment of adolescent-specific clinic spaces [13] improved viral outcomes.

Adolescents have been reported to have better viral outcomes when they had a person living with HIV in the same household or had been switched to a second line treatment $[25,34]$. In this study, although the majority (66.5\%) had members in their family living with a positive HIV status, there was no significant relationship with viral suppression. In addition, few adolescents (14\%) were switched to the second line treatment despite their viral outcome status. Majority (61\%) who had not achieved suppression had not been switched, and no markers were in place to prioritize for a change of regimen.

In this study, age and education (school attendance) were not significantly associated with viral load suppression. However, adolescents aged 12 and 16 years were more likely to have an unsuppressed viral load in both the initial and subsequent viral load despite consistently high levels of adherence and family support. This is contrary to the findings from other studies conducted in Uganda where adolescents who attended school were found with lower levels of adherence to treatment and older adolescents had high tendencies of missed scheduled appointments $[16,35]$.
This study had several limitations. Although our study was cross sectional in nature, we collected viral load results from secondary data. It is possible that the viral suppression status of some adolescents may have changed at the time of the study. We also sampled only those adolescents who had a viral load test result documented in their medical records between January 2015 and July 2016. Other limitations include limited knowledge and data about drug-resistance testing, missing data, the use of sub-optimal treatment regimens, limited sample size, and non-ascertainment of prior treatment interruptions (such as history of adherence since start of ART). For nutrition, we used the most current nutritional status of adolescents documented in the individual ART cards and could not rule out that nutritional status might have been different at time when the viral load test was taken. We restricted the sample to adolescents from the East Central region of Uganda; hence, our results could be different from those conducted in other settings. The need for caretaker's consent was a major obstacle especially when young adolescents reported to the clinic alone.

\section{Conclusion}

More than $70 \%$ of all adolescents who did not achieve viral suppression were sufficiently adherent (with adherence $>95 \%$ ). Adolescents who had unsuppressed viral loads in their initial viral load were more likely to experience virologic failure upon a repeat viral load regardless of their adherence level or change of regimen. The study also shows that strong religious beliefs exist among adolescents. Healthcare provider training in psychological counseling, regular and strict monitoring of adolescent outcomes should be prioritized to facilitate early identification and management of drug resistance through timely switching of treatment regimens to more robust combinations.

\section{Additional file}

Additional file 1: Table S1. Key characteristics of adolescents whose adherence level was good (> 95\%) but failed to achieve viral suppression $(n=49)$. (DOCX $13 \mathrm{~kb})$

\section{Abbreviations}

3TC: Lamivudine; ABC: Abacavir; AIDS: Acquired immune deficiency syndrome; AOR: Adjusted odds ratio; ART: Antiretroviral therapy; Cl: Confidence interval; EFV: Efavirenz; HIV: Human immunodeficiency virus; HIVDR: HIV drug resistance; NVP: Nevirapine; OpenMRS: Open Medical Records System; RRH: Regional Referral Hospital

Acknowledgements

We would like to acknowledge hospital staff and study participants in Uganda. We also thank Krishna Poudel and Kalpana Poudel of the University of Massachusetts Amherst, for their critical comments on this article. 


\section{Funding}

Not applicable.

\section{Availability of data and materials}

The datasets used and/or analyzed during the current study are available from the corresponding author on reasonable request.

\section{Authors' contributions}

NJ made substantial contributions to conception and design, acquisition of data, analysis and interpretation of data. KP made substantial contribution to the design of the data collection tools and interpretation of results. He was also involved in writing some sections of the manuscript. MJ has been involved in revising the manuscript critically for important intellectual content and has given final approval of the version to be published. AS and KICO have made substantial contribution to data analysis, interpretation, and writing of results. All authors read and approved the final manuscript.

\section{Ethics approval and consent to participate}

We obtained a waiver from the International Health Sciences University's Degree Research and Ethics Committee. The reason for the waiver was that the study had no potential to cause harm whether physical or psychological to the participants. The decision was based on the National Guidelines for Research involving humans as research participants developed by the Uganda National Council for Science and Technology. We also obtained permission from the hospital administration to conduct the study.

\section{Consent for publication}

All participants (adolescents or caretakers) involved in the study gave their consent to use the information collected for publication purposes.

\section{Competing interests}

The authors declare that they have no competing interests.

\section{Publisher's Note}

Springer Nature remains neutral with regard to jurisdictional claims in published maps and institutional affiliations.

\section{Received: 4 December 2018 Accepted: 6 January 2019} Published online: 17 January 2019

\section{References}

1. Joint United Nations Programme on HIV/AIDS (UNAIDS). Ending AIDS; Progress towards 90-90-90 targets. Geneva: UNAIDS; 2017

2. World Health Organization. A global research for adolescents living with HIV. Geneva: WHO; 2017

3. UNICEF. Analysis of UNAIDS 2016 estimates.

4. Bulage L, Ssewanyana I, Nankabirwa V, Nsubuga F, Kihembo C, Pande $\mathrm{G}$, et al. Factors associated with virological non-suppression among HIV-positive patients on antiretroviral therapy in Uganda August 2014-July 2015. BMC Infect Dis. 2017;17:326. https://doi.org/10.1186/ s12879-017-2428-3.

5. Boerma RS, Boender TS, Bussink AP, Calis JC, Bertagnolio S, Rinke de Wit TR, et al. Sub-optimal viral suppression rates among HIV-infected children in low-and middle- income countries: a meta-analysis. Clin Infect Dis. 2016; doi.org/10.1093/cid/ciw645.

6. World Health Organization. Prevent HIV, test and treat all. Geneva: World Health Organization; 2016.

7. Galea JT, Wong M, Muñoz M, Valle E, Leon SR, Perez DD, et al. Barriers and facilitators to antiretroviral therapy adherence among Peruvian adolescents living with HIV: a qualitative study. PLoS One. 2018;13:e0192791. https://doi. org/10.1371/journal.pone.0192791.

8. Shubber Z, Mills EJ, Nachega JB, Vreeman R, Freitas M, Bock P, et al. Patientreported barriers to adherence to antiretroviral therapy: a systematic review and meta-analysis. PLoS Med. 2016;13:e1002183. https://doi.org/10.1371/ journal.pmed.1002183.

9. Okawa S, Kabaghe SM, Mwiya M, Kikuchi K, Jimba M, Kankasa C, et al. Psychological well-being and adherence to antiretroviral therapy among adolescents living with HIV in Zambia. AIDS Care. 2018;30:634-42. https://doi.org/10.1080/09540121.2018.1425364.
10. McKinney O, Modeste NN, Lee JW, Gleason PC, Maynard-Tucker G Determinants of antiretroviral therapy adherence among women in Southern Malawi: Healthcare providers' perspectives. AIDS Res Treat. 2014; doi.org/10.1155/2014/489370.

11. Bereznicki LR, Peterson GM, Bimirew MA, Kassie DM. Barriers and facilitators of adherence to antiretroviral drug therapy and retention in care among adult HIV-positive patients: a qualitative study from Ethiopia. PLoS One. 2014;9:e97353. https://doi.org/10.1371/journal.pone.0097353.

12. Zanoni BC, Sibaya T, Cairns C, Lammert S, Haberer JE. Higher retention and viral suppression with adolescent-focused HIV clinic in South Africa. PLoS One. 2017;12:e0190260. https://doi.org/10.1371/journal.pone.0190260.

13. Ferrand RA, Simms V, Dauya E, Bandason T, Mchugh G, Mujuru H, et al. The effect of community-based support for caregivers on the risk of virological failure in children and adolescents with HIV in Harare, Zimbabwe (ZENITH): an open-label, randomized controlled trial. Lancet Child Adolesc Health. 2017;1:175-83. https://doi.org/10.1016/S2352-4642(17)30051-2.

14. Joint United Nations Programme on HIV/AIDS (UNAIDS). The Gap report: beginning of the end of the AIDS epidemic. Geneva: UNAIDS; 2014.

15. Ministry of health. Uganda HIV/AIDS country progress report July 2016-June 20. Reaching men, girls and young women to reduce new HIV infections. 2017.

16. Kamya M, Mayanja-kizza H, Kambugu A, Bakeera-kitaka S, Semitala F, Mwebaze-songa $P$, et al. Predictors of long-term viral failure among Ugandan children and adults treated with antiretroviral therapy. J Acquir Immune Defic Syndr. 2007;46:187-93. https://doi.org/10.1097/QAl. Ob013e31814278c0

17. Duarte HA, Harris DR, Tassiopolous K, Leister E, Fabiana S, Ferreira FF, et al. Relationship between viral load and behavioral measures of adherence to antiretroviral therapy in children living with human immunodeficiency virus in Latin America. Braz J Infect Dis. 2015;19:263-71. https://doi.org/10.1016/j. bjid.2015.01.004

18. Glass TR, Rotger M, Telenti A, Decosterd L, Csajka C, Bucher HC, et al. Determinants of sustained viral suppression in HIV-infected patients with self-reported poor adherence to antiretroviral therapy. PLoS One. 2012:7:e29186. https://doi.org/10.1371/journal.pone.0029186.

19. Williams PL, Storm D, Montepiedra G, Nichols S, Kammerer B, Sirois PA, et al. Predictors of adherence to antiretroviral medications in children and adolescents with HIV infection. J Pediatr. 2006;118:e1745-57. https://doi.org/ 10.1542/peds.2006-0493.

20. Ministry of Health, Uganda. Consolidated guidelines for prevention and treatment of HIV in Uganda. 2016.

21. World Health Organization. Technical and operational considerations for implementing HIV viral load testing; Interim update. Geneva: WHO; 2014. https://www.who.int/hiv/pub/arv/viral-load-testing-technical-update/en.

22. Nlend N, Esther A, Annie Nga M, Suzie Tetang N, Joseph F. Predictors of virologic failure on first-line antiretroviral therapy among children in a referral pediatric center in Cameroon. Pediatr Infect Dis J. 2017;362. https://doi.org/10.1097/INF.0000000000001672.

23. Buma D, Bakari M, Fawzi W, Mugusi F. The influence of HIV-status disclosure on adherence, immunological and virological outcomes among HIV-infected patients started on antiretroviral therapy in Dar-es-Salaam, Tanzania. J HIV AIDS. 2015:1 doi. org/https://doi.org/10.16966/2380-5536.111.

24. Agwu AL, Fairlie L. Antiretroviral treatment, management challenges and outcomes in perinatally HIV-infected adolescents. Int AIDS Soc. 2013;16:18579. doi.org/10.7448/IAS.16.1.18579.

25. Sithole Z, Mbizvo E, Chonzi P, Mungati M, Juru TP, Shambira G, et al. Virological failure among adolescents on ART, Harare City, 2017- a casecontrol study. BMC Infect Dis. 2018;18:469. https://doi.org/10.1186/s12879018-3372-6.

26. Nasuuna E, Kigozi J, Babirye L, Muganzi A, Sewankambo NK, Nakanjako D. Low HIV viral suppression rates following the intensive adherence counseling (IAC) program for children and adolescents with viral failure in public health facilities in Uganda. BMC Public Health. 2018:1048.ty 0 doi.org/10.1186/s12889-018-5964-x

27. World Health Organization. HIV drug resistance report 2017. Geneva: WHO; 2017. http://apps.who.int/iris/bitstream/handle/10665/128121/ 9789241507578 eng.pdf;jsessionid= 1FB8247E8E38F2A921196BE73B49DAEDsequence=1.

28. Geary RS, Gómez-Olivé FX, Kahn K, Tollman S, Norris SA. Barriers to and facilitators of the provision of a youth-friendly health services programme in rural South Africa. BMC Health Serv Res. 2014;14:259. https://doi.org/10. 1186/1472-6963-14-259. 
29. Pillay P, Ford N, Shubber Z, Ferrand RA. Outcomes for efavirenz versus nevirapine-containing regimens for treatment of HIV-1 infection: a systematic review and meta-analysis. PLoS One. 2013;8:e68995. 238943930.

30. Bayu B, Tariku A, Bulti AB, Habitu YA, Derso T, Teshome DF. Determinants of virological failure among patients on highly active antiretroviral therapy in University of Gondar Referral Hospital, Northwest Ethiopia: a case-control study. J HIV AIDS. 2017;9:153-9. https://doi.org/10.2147/HIV.S139516.

31. Jobanputra K, Parker LA, Azih C, Okello V, Maphalala G, Kershberger B, et al. Factors associated with virological failure and suppression after enhanced adherence counselling, in children, adolescents and adults on antiretroviral therapy for HIV in Swaziland. PLoS One 2015;10:e0116144. https://doi.org/10 1371/journal.pone.0116144.

32. Nachega JB, Marconi VC, van Zyl GU, Gardner EM, Preiser W, Hong SY, et al. HIV treatment adherence, drug resistance, virologic failure: evolving concepts. Infect Disord Drug Targets. 2011:11(2):167-74.

33. Lowenthal ED, Ellenberg JH, Machine E, Sagdeo A, Boititswe S, Steenhoff AP, et al. Association between efavirenz-based compared with nevirapinebased antiretroviral regimens and virological failure in HIV-infected children. JAMA. 2013;309:1803-9. https://doi.org/10.1001/jama.2013.3710.

34. Kyaw NT, Harries AD, Kumar AM, Oo MM, Kyaw KW, Win T, et al. High rate of virological failure and low rate of switching to second-line treatment among adolescents and adults living with HIV on first-line ART in Myanmar, 2005-2015. PLoS One. 2017;12(2):e0171780. https://doi.org/10.1371/journal. pone.0171780.

35. MacCarthy S, Saya U, Samba C, Birungi J, Okoboi S, Linnemayr S. "How am I going to live?": exploring barriers to ART adherence among adolescents and young adults living with HIV in Uganda. BMC public health. 2018;18(1):1158. https://doi.org/10.1186/s1 2889-018-6048-7.

Ready to submit your research? Choose BMC and benefit from:

- fast, convenient online submission

- thorough peer review by experienced researchers in your field

- rapid publication on acceptance

- support for research data, including large and complex data types

- gold Open Access which fosters wider collaboration and increased citations

- maximum visibility for your research: over $100 \mathrm{M}$ website views per year

At $\mathrm{BMC}$, research is always in progress.

Learn more biomedcentral.com/submissions 